Proc. Estonian Acad. Sci. Geol., 2002, 51, 3, 143-156

\title{
Correlation of Telychian sections from shallow to deep sea facies in Estonia and Latvia based on the sanidine composition of bentonites
}

\author{
Tarmo Kiipli and Toivo Kallaste ${ }^{\mathrm{b}}$ \\ ${ }^{a}$ Mining Institute, Tallinn Technical University, Kopli 82, 10142 Tallinn, Estonia; \\ tarmo.kiipli@egk.ee \\ b Institute of Geology, Tallinn Technical University, Estonia pst. 7, 10143 Tallinn, Estonia; \\ kallaste@egk.ee
}

Received 22 October 2001, in revised form 23 January 2002

\begin{abstract}
Sanidine composition of 130 samples of bentonites from 12 sections of Telychian (some possibly Sheinwoodian) age was analysed by X-ray diffractometry for correlation purposes. Solid solution of magmatic sanidine contained $20-47 \% \mathrm{NaAlSi}_{3} \mathrm{O}_{8}$ molecules. The sanidine composition is very individual for many beds and can be used successfully for correlations.
\end{abstract}

Key words: sanidine, bentonites, correlation, Silurian.

\section{INTRODUCTION}

The idea that volcanic ash beds in sedimentary sections can be used as perfect time markers for correlations was proposed long ago (e.g. Spjeldnæs 1959). Although now tephrochronology is used successfully in Quaternary geology and archaeology, identification of coeval ash beds in the Palaeozoic rocks appears to be more complicated. The reason is that the ash consists mainly of unstable amorphous material which recrystallizes easily in exogenic environments. As a result, various clay minerals and other authigenic silicates form (Ross \& Shannon 1926; Grim \& Güven 1978; Altaner et al. 1984; Caballero et al. 1992; Huff et al. 1996; Kiipli et al. 1997). Therefore, main chemical components and minerals cannot be used directly for correlation of ancient volcanic beds. Some elements exhibit low mobility in exogenic environments and can be used for restoring source magma in altered volcanic rocks (Winchester \& Floyd 1977). Correlation on the basis of immobile trace elements has been successfully used in many works (Huff \& Kolata 1989; Batchelor \& Jeppsson 1994; Bergström et al. 1995; Kiipli et al. 2001). Attempts to correlate ash beds from different facies may still 
fail due to the variable degree of residual enrichment of material with immobile elements in different environments. Also, no element can be strictly defined as immobile - even the low mobility elements can move to some extent. The study of trace magmatic minerals allows us to overcome these problems and to identify the bentonites. In the present study we used the composition of magmatic sanidine to recognize coeval volcanic beds in different sections.

\section{TELYCHIAN SECTIONS IN ESTONIA AND LATVIA}

The Llandovery-Wenlock boundary interval in Estonia, corresponding to a relatively high sea level period (Johnson et al. 1991), is represented by up to $95 \mathrm{~m}$ thick claystones and marlstones lying between nodular limestones (Rumba Formation) and reef and lagoonal dolostones (Jaagarahu and Muhu formations). In these rocks the Adavere and Jaani regional stages are distinguished (Fig. 1). The former has been correlated with the Upper Llandovery and the latter with the Lower Wenlock (Aaloe 1960; Kaljo 1962; Nestor 1997). In a relatively homogeneous claystone-marlstone sequence the boundary of these regional stages is often placed at different levels in different sections, and even in one section. For example, in the Viki core this boundary has been established at the following depths: $153.8 \mathrm{~m}$ (Jeppsson \& Männik 1993), $135 \mathrm{~m}$ (Nestor 1994, fig. 14), $145.8 \mathrm{~m}$ (Nestor 1994, table 4 combined with fig. 3; Nestor 1997, fig. 65), $133.5 \mathrm{~m}$ (Nestor 1997, fig. 69). The cause of such indistinctness is different palaeontological or lithological criteria used by different authors. The original criterion for this boundary used by Aaloe (1960) was the uppermost one of the volcanic ash beds in the interval of their frequent occurrence. In the Viki core, it lies at $145.7 \mathrm{~m}$, close to the beginning of the Pterospathodus amorphognathoides amorphognathoides conodont Zone (Kiipli et al. 2001).

In the Ohesaare core, represented by the graptolite facies, the LlandoveryWenlock boundary was placed at the volcanic ash bed at a depth of $345.8 \mathrm{~m}$. Cyrtograptus murchisoni occurs $0.7 \mathrm{~m}$ above this ash bed (Kaljo 1962). Later,

\begin{tabular}{|c|c|c|c|}
\hline \multirow{2}{*}{$\begin{array}{c}\text { INTERNATIONAL } \\
\text { SERIES }\end{array}$} & \multicolumn{2}{|c|}{ ESTONIA } & LATVIA \\
\cline { 2 - 3 } & $\begin{array}{c}\text { REGIONAL } \\
\text { STAGES }\end{array}$ & FORMATIONS & FORMATIONS \\
\hline \multirow{2}{*}{ Wenlock } & Jaagarahu & Jaagarahu & \multirow{2}{*}{ Riga } \\
\cline { 2 - 3 } & Jaani & Jaani & Jurmala \\
\hline \multirow{2}{*}{ Llandovery } & Adavere & Velise & Dobele \\
\cline { 2 - 3 } & Raikküla & Raikküla & Roba \\
\cline { 2 - 3 } & & &
\end{tabular}

Fig. 1. Stratigraphic chart according to Nestor (1997) and Kaljo et al. (1998). 
the lowermost findings of this graptolite have been identified as Cyrtograptus centrifugus (Loydell et al. 1998). This level lies in the middle of the Pterospathodus amorphognathoides amorphognathoides Zone (Loydell et al. 1998, and correlation of bentonites in the present study), therefore clearly higher than the Adavere-Jaani boundary in the northern, shallower palaeoshelf sections.

In Latvia, Telychian sections are represented by red, grey, and variegated claystones above dark organic-rich argillites of the Dobele Formation. The upper boundary is not marked lithologically and can be established only by the appearance of Wenlock graptolites.

\section{MATERIAL AND METHODS}

A total of 130 samples from 12 cores were studied from volcanic beds with a thickness between 0.2 and $25 \mathrm{~cm}$ (Fig. 2). The same samples from six cores, representing relatively shallow palaeosea facies, were formerly used in Kiipli et al. (2001) for correlating sections on the basis of immobile trace elements. Two

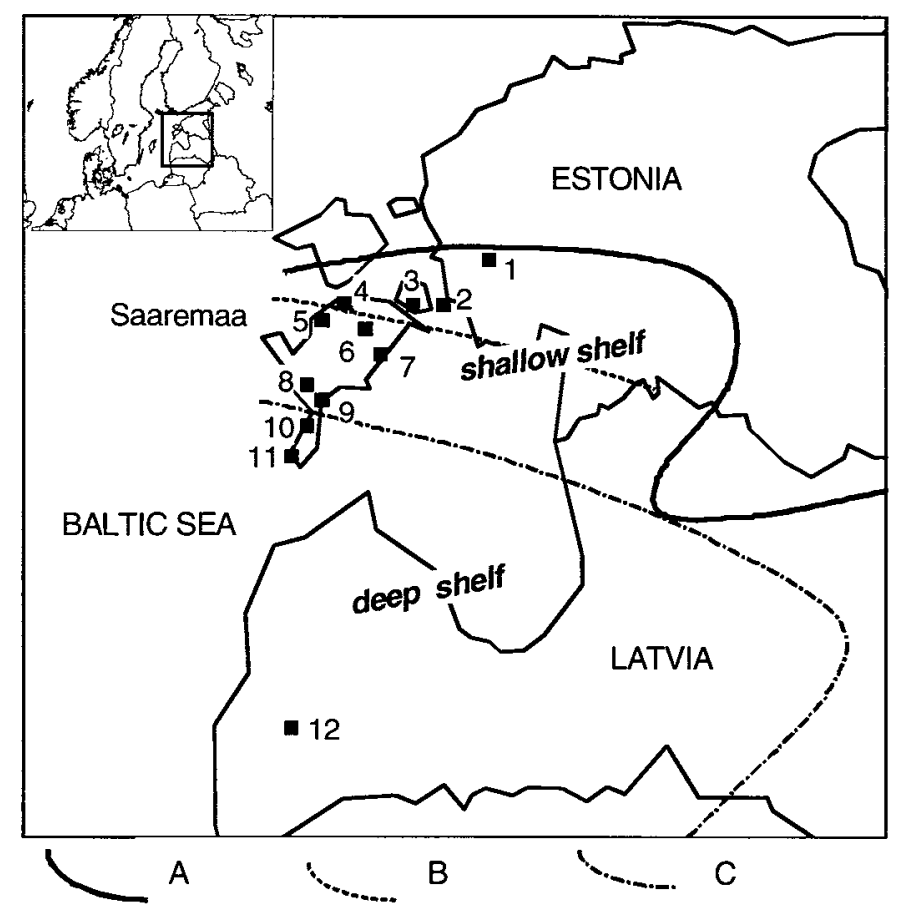

Fig. 2. Location of the studied sections and distribution of Velise sediments. A, erosional margin of Velise sediments; B, boundary between calcareous marlstones and carbonate claystones; $\mathrm{C}$, boundary between carbonate claystones and claystones. 1, Kirikuküla; 2, Viirelaid; 3, Lõetsa; 4, Pahapilli; 5, Mustjala; 6, Valjala; 7, Nässumaa; 8, Viki; 9, Tehumardi; 10, Kaugatuma; 11, Ohesaare; 12, Aizpute. 
sections of the present study (Aizpute and Ohesaare) are located in the deep shelf facies and one (Kaugatuma) lies near the boundary between the deep and shallow shelf facies. Mineralogy of volcanic beds is different from that of host rock. In the volcanic beds illite-smectite, kaolinite, and potassium feldspar (authigenic $\mathrm{K}$-sanidine) dominate. The host rock is composed mainly of illite, potassium feldspar (orthoclase), and terrigenous quartz. Coarse fractions contain euhedral and broken magmatic quartz, biotite, and $\mathrm{K}-\mathrm{Na}$ sanidine. The estimated content of magmatic phenocrysts was $1-10 \%$ of the bulk sediment. According to Kastner (1971) and Kastner \& Siever (1979), sedimentary authigenic feldspars have a pure end member composition. Sanidine formation in magmatic processes, on the contrary, is characterized by a variable $\mathrm{K}$ to $\mathrm{Na}$ ratio in solid solution. Therefore, for correlation purposes we studied magmatic $\mathrm{K}-\mathrm{Na}$ sanidine. The presence of sanidine of variable composition in Silurian bentonites of Gotland was established by Snäll (1977), but was not used for correlation of sections.

\section{Sample preparation}

About 1-5 g of a sample was suspended ultrasonically in distilled water and after $20 \mathrm{~s}$ the clay suspension was poured out. If kaolinite was still present in coarse fraction, it was disperged ultrasonically in $20 \% \mathrm{KOH}$ solution and poured out. The residue was treated by hot $2 \mathrm{~N} \mathrm{HCl}$ solution, to clean the sample of hematite, calcite, apatite, and products of pyrite oxidation (gypsum, Fe-sulphates). The cleaned coarse fraction still contained, besides magmatic minerals ( $\mathrm{K}-\mathrm{Na}$ sanidine, quartz, biotite, zircon), also authigenic K-sanidine, pyrite or chalcopyrite. In a few samples barite occurred. The content of these minerals varied largely. Sulphides were removed by nitric acid. If the sample was large enough, the $0.04-0.1 \mathrm{~mm}$ and $0.1-0.25 \mathrm{~mm}$ fractions were separated by sieving. Pyroclastic grains larger than $0.25 \mathrm{~mm}$ were not found. The $0.1-0.25 \mathrm{~mm}$ fraction was present only in some beds, $0.04-0.1 \mathrm{~mm}$ fraction was established in all beds and therefore suits best for correlation studies. The fine $(<0.04 \mathrm{~mm})$ fraction is not suitable for the study of magmatic sanidine due to a higher content of authigenic $\mathrm{K}$-sanidine, which complicates also analysis of coarser fractions. In the case of feldspathites (volcanogenic interbeds consisting mostly of authigenic potassium feldspar), it is impossible to achieve the concentration of magmatic phenocrysts sufficient for detailed study. For XRD analysis the sample was ground by hand in an agate mortar and a slurry mount was prepared using ethyl alcohol and glass slide.

\section{Measurements}

Measurements were performed on the HZG-4 diffractometer (Freiberger Präzisionmechanik) using Fe-filtered Co-radiation. All samples were routinely scanned from 5 to $45^{\circ} 2 \theta$ before any treatment in order to check their volcanic origin and estimate the mineralogical composition. From the separated fraction 
the $20 \overline{1}$ reflection of sanidine was measured with maximum accuracy. An angle range from 23.5 to $26.0^{\circ} 2 \theta$ was scanned with the step size $0.01^{\circ} 2 \theta$; the measuring time was $15 \mathrm{~s}$ per point. This range includes the 100 reflection of quartz, the $20 \overline{1}$ reflection of various feldspar phases, and also 4.18 and $4.13 \AA$ reflections of kaolinite. Therefore, removal of kaolinite from the sample before measurements is essential.

\section{Calculation of the sanidine composition}

A curve-fitting programme performed in MathCad 2000 was applied for calculating the exact peak position, half-width, and intensity. The measured X-ray pattern was fitted with convolution of mineral reflection and instrumental profile. The profile of quartz heated for $7 \mathrm{~h}$ at $800^{\circ} \mathrm{C}$ was used as instrumental profile. The peak position, half-width, and intensity were calculated for four components: quartz, K-sanidine, and two K-Na sanidines. The K-Na sanidine peak position was calculated in relation to quartz or K-sanidine, depending on which of these minerals dominated in a specimen. The angle distance between quartz and K-sanidine reflections appeared to be constant, pointing to the stable composition of both minerals. Only rare traces of plagioclase were detected and therefore plagioclase reflection was not included in curve-fitting. Examples of the measured diffractograms are shown in Fig. 3.

The content of $\mathrm{NaAlSi}_{3} \mathrm{O}_{8}$ in mol\% in $\mathrm{K}-\mathrm{Na}$ sanidine was calculated according to Orville (1967), who established that the position of the $20 \overline{1}$ reflection almost linearly depends on the composition of sanidine solid solution. Fast cooling of volcanic ash avoids exsolution of feldspar and favours the preservation of magmatic sanidine; therefore calculation of the feldspar composition according to the method proposed by Orville can be estimated as accurate. In perthites, calculation of the sanidine composition on the basis of only the $20 \overline{1}$ reflection can lead to imprecise results because of the strain between two feldspar phases (Stewart \& Wright 1974). Late recrystallization of magmatic sanidine resulting in perthite formation supposedly did not take place because the rocks have not been heated more than $50-100^{\circ} \mathrm{C}$ during the geological history, as indicated by the alteration index of conodonts, which varies between 1 and 2 in the Silurian and Ordovician rocks of Estonia (Männik \& Viira 1990). The precision of the analysis of the $\mathrm{K}-\mathrm{Na}$ sanidine composition is $\pm 1 \%$ in favourable cases (low intensity of authigenic feldspar reflection, no kaolinite, high intensity of the magmatic sanidine reflection) and $\pm 2 \%$ in less favourable cases.

\section{RESULTS}

$\mathrm{K}-\mathrm{Na}$ sanidine of various composition was found, containing $20-47 \mathrm{~mol} \%$ $\mathrm{NaAlSi}_{3} \mathrm{O}_{8}$. In a few bentonite samples magmatic sanidine was at the level of the detection limit. Magmatic sanidine was not found in terrigenous samples. The 


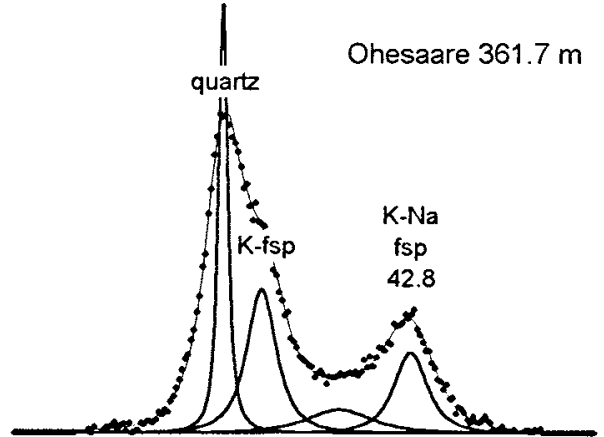

Ohesaare $362.23 \mathrm{~m}$
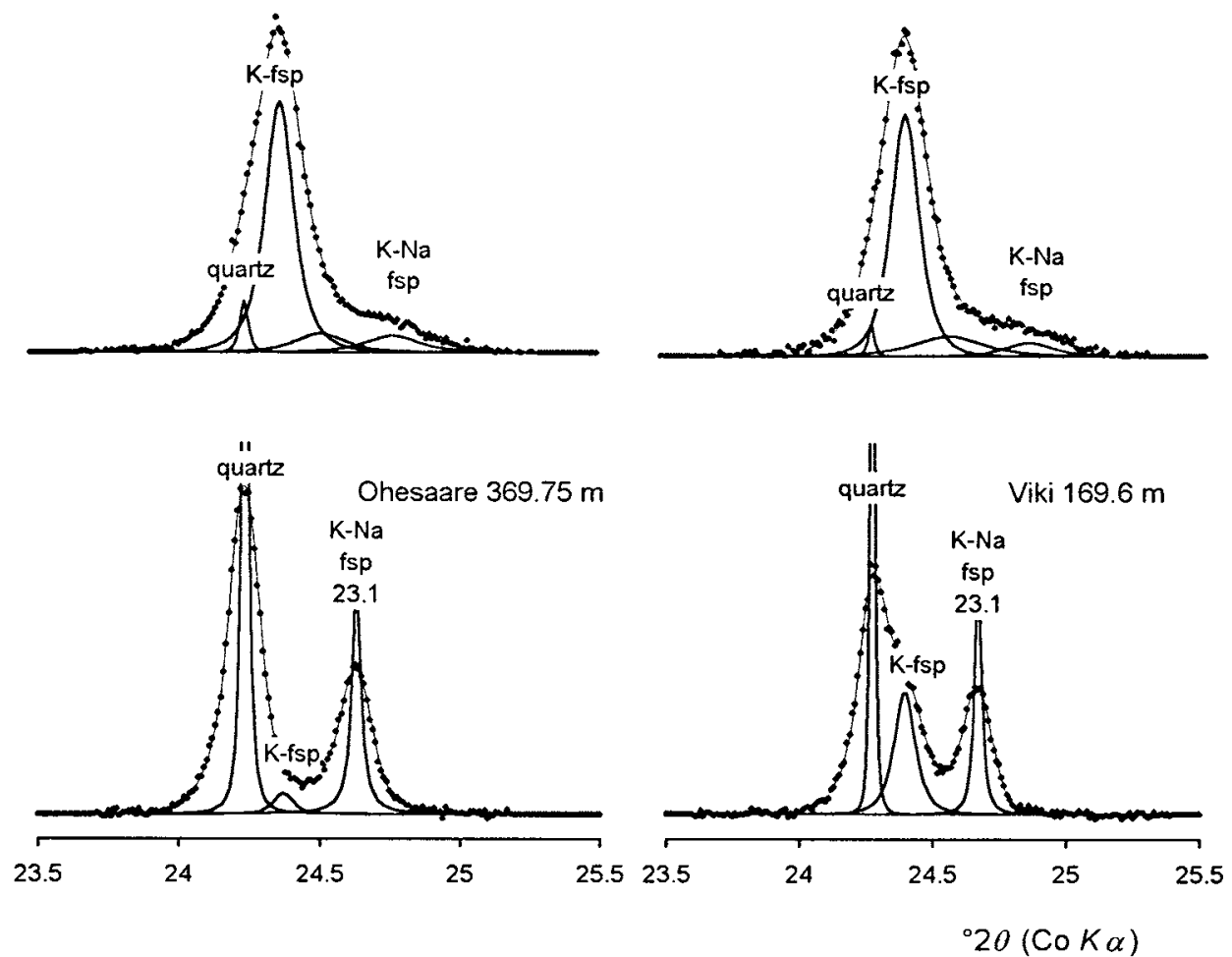

Fig. 3. Examples of measured X-ray diffraction patterns from 23.5 to 25.5 deg $2 \theta$ (Fe-filtered Co-radiation). The measured curve is marked with dots. Solid curves represent the result of curvefitting. The uppermost and lowermost examples represent $\mathrm{K}-\mathrm{Na}$ sanidine with sharp reflection, allowing good correlations. The intermediate examples represent $\mathrm{K}-\mathrm{Na}$ sanidine with wide reflection impossible to use for correlation. $\mathrm{K}-\mathrm{fsp}=\mathrm{K}$-feldspar; $\mathrm{K}-\mathrm{Na}$ fsp $=\mathrm{K}-\mathrm{Na}$ feldspar; the number shows the content of $\mathrm{NaAlSi}_{3} \mathrm{O}_{8}$ in $\mathrm{mol} \%$ in sanidine. 
rest of the volcanic samples contained a measurable amount of $\mathrm{K}-\mathrm{Na}$ sanidine. Two groups of samples can be distinguished: (1) The samples exhibiting a wide elevated interval in XRD spectra without a specific well distinguishable reflection. This type can be interpreted as containing a mixture of $\mathrm{K}-\mathrm{Na}$ sanidine of variable composition. Correlation of this type is not certain and can be done with some probability between beds with signs allowing better identification. Twelve of the studied beds show this type of sanidine pattern. (2) The samples exhibiting well measurable reflections and allowing calculations of the $\mathrm{K}-\mathrm{Na}$ sanidine composition. These beds can be found and correlated in the studied sections with a high level of probability. Twenty-three of the studied beds revealed well measurable sanidine reflections. The reflection width varied largely and in case of wide reflections the XRD pattern was transitional between two types. Commonly, even in the presence of a sharp K-Na sanidine peak, a wide elevated region in spectra was observed. Therefore, curve-fitting with three components (quartz, K-sanidine, and one $\mathrm{K}-\mathrm{Na}$ sanidine) was only rarely satisfactory, but four-component fitting revealed good results in all cases (Fig. 3). Twenty-nine volcanic beds are correlated in at least two core sections; 18 of these can be identified in four or more sections. Eight volcanic beds were identified only in one section (Table 2). A total of 37 volcanic beds were established in the Telychian sequence of Estonia and Latvia. The maximum number of volcanic beds in a single section is 23 (Ohesaare). In Table 1 two formerly published numbering systems are presented (Kiipli 1998; Kiipli et al. 2001), both beginning with zero (0) which designates the bentonite well known in Estonia as "O". This bed was named Osmundsberg K-bentonite by Bergström et al. (1998). With only a few corrections correlations by sanidine compositions well correspond to the correlations formerly performed by trace elements (Kiipli et al. 2001). Present correlations well concord with biostratigraphy (Jeppsson \& Männik 1993; Loydell et al. 1998) but allow also some refinements in the correlation of graptolite and conodont biozones. More detailed biostratigraphical analysis is currently under preparation.

\section{SOME PROBLEMS}

Until the bed has been identified in at least two sections, its stratigraphic position cannot be considered as proved. For example, in the Mustjala core two beds, at 115.87 and $117.80 \mathrm{~m}$, can be well characterized by their sanidine compositions, but in other cores beds with a similar composition have opposite succession. The bed at $115.87 \mathrm{~m}$ in Mustjala can be correlated with the bed at $191.95 \mathrm{~m}$ in Tehumardi and the bed at $117.80 \mathrm{~m}$ in Mustjala with the bed at $190.30 \mathrm{~m}$ in Tehumardi. Thus, this part of the Mustjala core is possibly not in right order in the core box or one of these beds is new in Mustjala, not found in other cores. Considering graphic correlations based on currently available information, we chose a preliminary correlation as presented in Tables 1 and 2. 
Table 1. Correlated volcanic beds (rows) from the studied core sections (depth in metres)

\begin{tabular}{|c|c|c|c|c|c|c|c|c|c|}
\hline $\begin{array}{c}\text { Bed No. } \\
\text { (Kiipli } \\
1998)\end{array}$ & $\begin{array}{c}\text { Bed No. } \\
\text { (Kiipli } \\
\text { et al. } \\
2001 \text { ) }\end{array}$ & $\begin{array}{c}\text { Kiriku- } \\
\text { küla* }\end{array}$ & $\begin{array}{l}\text { Viire- } \\
\text { laid* }\end{array}$ & Lõetsa* & $\begin{array}{l}\text { Paha- } \\
\text { pilli* }\end{array}$ & Valjala* & $\begin{array}{l}\text { Must- } \\
\text { jala }\end{array}$ & $\begin{array}{c}\text { Nässu- } \\
\text { maa* }^{*}\end{array}$ & Viki* \\
\hline 25 & 29 & & & & & 113.80 & & & \\
\hline 24 & 28 & & & & & & & & 115.02 \\
\hline \multirow[t]{2}{*}{23} & 27 & & & & 20.85 & 119.80 & & & 121.03 \\
\hline & new & & & & & & 69.80 & & 131.10 \\
\hline 22 & 26 & 12.59 & & & & & 82.08 & 199.70 & 145.75 \\
\hline 20 & 23 & 15.80 & 65.90 & 44.40 & 40.30 & & & 200.70 & 147.50 \\
\hline 19 & 21 & & & & & & & & 148.00 \\
\hline 18 & 22 & 17.20 & & & & & 85.40 & & 148.80 \\
\hline \multirow{2}{*}{17} & 19 & 17.85 & 66.60 & 45.10 & & & 85.79 & 201.80 & 149.40 \\
\hline & 18 & & 67.75 & & & & & & 151.80 \\
\hline 16 & 17 & & 68.30 & 47.20 & 45.20 & & & & \\
\hline \multirow[t]{2}{*}{14} & 16 & & & & 46.20 & & & & 152.10 \\
\hline & new & & & & & & & & \\
\hline \multirow[t]{3}{*}{12} & 15 & 28.25 & & & 51.50 & & 94.00 & & 156.80 \\
\hline & new & & & & & & & & \\
\hline & 14 & & 76.45 & & & & & & \\
\hline 11 & 13 & & 76.70 & 56.80 & 61.70 & & 105.95 & 219.40 & 169.60 \\
\hline 9 & 12 & & 77.60 & 57.70 & 64.60 & & 109.63 & & 171.95 \\
\hline 8 & 11 & & 78.11 & & 65.65 & 153.40 & & & 173.10 \\
\hline 7 & 10 & & 78.20 & & & & 111.95 & & 174.40 \\
\hline 6 & 9 & & 78.48 & & 67.00 & & & & 175.55 \\
\hline \multirow[t]{2}{*}{5} & 7 & & 79.13 & & 68.50 & & & & \\
\hline & 6 & & 79.38 & & & & & & \\
\hline \multirow[t]{2}{*}{4} & 5 & & & & & & & & 178.80 \\
\hline & new & & & & & & 117.80 & & \\
\hline 3 & 4 & & & & & & & & 181.80 \\
\hline 2 & 3 & & & & 72.20 & & & & 182.30 \\
\hline 1 & 2 & & & & & & & & 184.35 \\
\hline 0 & 0 & 38.16 & 85.00 & 66.00 & 78.35 & 165.40 & 124.70 & 235.10 & 185.10 \\
\hline
\end{tabular}


Table 1. Continued

\begin{tabular}{|c|c|c|c|c|c|c|c|}
\hline \multirow{2}{*}{$\begin{array}{c}\text { Bed No. } \\
\text { (Kiipli } \\
1998)\end{array}$} & \multirow{2}{*}{$\begin{array}{l}\text { Bed No. } \\
\text { (Kiipli } \\
\text { et al. } \\
2001 \text { ) }\end{array}$} & \multirow[t]{2}{*}{$\begin{array}{l}\text { Tehu- } \\
\text { mardi }\end{array}$} & \multirow[t]{2}{*}{$\begin{array}{l}\text { Kauga- } \\
\text { tuma }\end{array}$} & \multirow[t]{2}{*}{$\begin{array}{l}\text { Ohe- } \\
\text { saare }\end{array}$} & \multirow[t]{2}{*}{ Aizpute } & \multicolumn{2}{|c|}{$\begin{array}{l}\text { Main component } \\
\text { of } \mathrm{K}-\mathrm{Na} \text { sanidine }\end{array}$} \\
\hline & & & & & & $\begin{array}{c}\mathrm{NaAlSi}_{3} \mathrm{O}_{8} \\
\mathrm{~mol} \%\end{array}$ & $\begin{array}{l}\text { Width of the } \\
\text { reflection, deg }\end{array}$ \\
\hline 25 & 29 & & & 340.76 & & \multicolumn{2}{|c|}{$\begin{array}{l}\text { Much of biotite and quartz, } \\
\text { little sanidine }\end{array}$} \\
\hline 24 & 28 & & 236.90 & 342.08 & 917.10 & $35.2-35.8$ & $0.19-0.34$ \\
\hline \multirow[t]{2}{*}{23} & 27 & & 243.20 & 345.83 & 925.80 & $38-40$ & $0.25-0.35$ \\
\hline & new & & 256.00 & 351.72 & 931.80 & $36.2-37.8$ & $0.08-0.12$ \\
\hline 22 & 26 & 163.91 & 258.90 & 359.31 & & \multicolumn{2}{|c|}{ Very wide reflection } \\
\hline 20 & 23 & & & 361.30 & & $45.2-46.3$ & $0.12-0.20$ \\
\hline 19 & 21 & & 261.10 & 361.70 & 938.00 & $42.0-42.8$ & $0.18-0.27$ \\
\hline 18 & 22 & 165.90 & & 362.23 & 941.35 & \multicolumn{2}{|c|}{ Very wide reflection } \\
\hline \multirow[t]{2}{*}{17} & 19 & 166.70 & 261.50 & 362.46 & & $45.7-46.4$ & $0.05-0.09$ \\
\hline & 18 & & 263.10 & 364.76 & 943.90 & \multicolumn{2}{|c|}{ Very wide reflection } \\
\hline 16 & 17 & & & 365.08 & 946.90 & \multicolumn{2}{|c|}{ Very wide reflection } \\
\hline \multirow[t]{2}{*}{14} & 16 & & & & 950.10 & \multicolumn{2}{|c|}{ Very wide reflection } \\
\hline & new & & 264.80 & 367.39 & 951.20 & $45.0-45.8$ & $0.12-0.17$ \\
\hline \multirow[t]{3}{*}{12} & 15 & 170.30 & 264.90 & 367.60 & 951.70 & \multicolumn{2}{|c|}{ Very wide reflection } \\
\hline & new & & & 369.12 & 953.99 & 45.5 & 0.09 \\
\hline & 14 & & & 369.72 & & 22.6 & 0.05 \\
\hline 11 & 13 & & 267.00 & 369.75 & 954.20 & $22.9-23.3$ & $0.04-0.06$ \\
\hline 9 & 12 & & 267.10 & & & \multicolumn{2}{|c|}{$\begin{array}{l}\text { Much of biotite and quartz, } \\
\text { little sanidine }\end{array}$} \\
\hline 8 & 11 & 184.03 & & 369.98 & 957.10 & $38.7-40.3$ & $0.10-0.16$ \\
\hline 7 & 10 & 185.10 & 267.20 & & 957.75 & $25.8-26.7$ & $0.07-0.10$ \\
\hline 6 & 9 & 185.80 & & 370.09 & & $25.5-26.2$ & $0.25-0.30$ \\
\hline \multirow[t]{2}{*}{5} & 7 & 186.70 & & 370.44 & & $20.5-24.1$ & $0.30-0.34$ \\
\hline & 6 & 187.65 & & 370.63 & 960.20 & $28.1-28.8$ & $0.07-0.08$ \\
\hline \multirow[t]{2}{*}{4} & 5 & 188.10 & & & & $40.1-40.6$ & $0.17-0.19$ \\
\hline & new & 190.30 & 268.60 & & & $24.5-25.3$ & $0.05-0.11$ \\
\hline 3 & 4 & & & & & \multicolumn{2}{|c|}{ Very wide reflection } \\
\hline 2 & 3 & 191.95 & & 370.77 & & $45.2-47.6$ & $0.12-0.17$ \\
\hline 1 & 2 & & & & 963.80 & \multicolumn{2}{|c|}{ Very wide reflection } \\
\hline 0 & 0 & 193.70 & 269.60 & & 964.40 & $20.7-21.5$ & $0.05-0.09$ \\
\hline
\end{tabular}

Bold - volcanic beds where sanidine was studied; normal font - beds correlated by trace elements; small font - supposed correlations.

* Cores where trace elements were studied in volcanic beds (Kiipli 1998; Kiipli \& Tsegelnjuk 2001). 


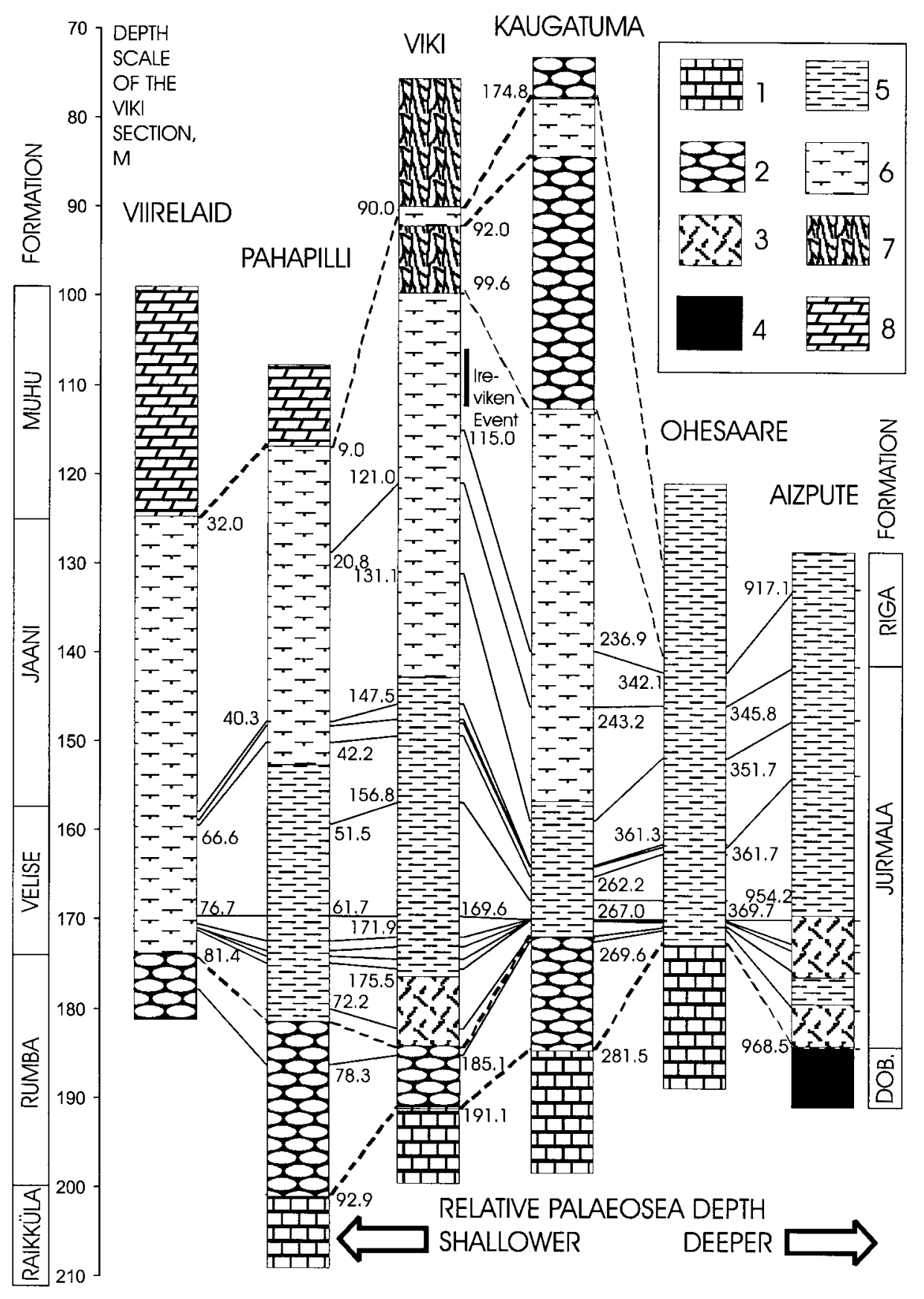

Fig. 4. Correlation of the studied sections. 1, micritic limestone; 2, nodular wackestone; 3, red and variegated shales; 4, dark organic-rich shales; 5, grey shales; 6, marlstones; 7 , reef and breccia dolostones; 8, microcrystalline bedded dolostone. Solid lines show volcanic ash correlations and dashed lines show litho- and biostratigraphic correlations. DOB. = Dobele Formation. 
Table 2. List of volcanic beds not correlated with other sections

\begin{tabular}{|c|c|c|c|c|c|}
\hline \multirow{2}{*}{$\begin{array}{c}\text { Bed No. } \\
\text { (Kiipli } \\
\text { 1998) }\end{array}$} & \multirow{2}{*}{$\begin{array}{l}\text { Bed No. } \\
\text { (Kiipli } \\
\text { et al. } \\
2001 \text { ) }\end{array}$} & \multirow[b]{2}{*}{ Core } & \multirow{2}{*}{$\begin{array}{l}\text { Depth, } \\
\text { m }\end{array}$} & \multicolumn{2}{|c|}{$\begin{array}{l}\text { Main component } \\
\text { of K-Na sanidine }\end{array}$} \\
\hline & & & & $\begin{array}{l}\mathrm{NaAlSi}_{3} \mathrm{O}_{8} \\
\mathrm{~mol} \%\end{array}$ & $\begin{array}{l}\text { Width of the } \\
\text { reflection, deg }\end{array}$ \\
\hline \multirow[t]{7}{*}{21} & 25 & Kirikuküla & 15.50 & \multicolumn{2}{|c|}{ Very wide reflection } \\
\hline & 4 & Viirelaid & 79.44 & $26.2^{\circ}$ & 0.26 \\
\hline & & Mustjala & 115.87 & 47.3 & 0.12 \\
\hline & & Tehumardi & 179.90 & \multicolumn{2}{|c|}{ Very wide reflection } \\
\hline & & Kaugatuma & 262.20 & 46.6 & 0.08 \\
\hline & & Ohesaare & 370.99 & 35.3 & 0.19 \\
\hline & & Aizpute & 956.30 & \multicolumn{2}{|c|}{ Very wide reflection } \\
\hline-1 & -1 & Pahapilli & 83.85 & \multicolumn{2}{|c|}{ Very wide reflection } \\
\hline
\end{tabular}

Several volcanic beds of the Aizpute core with wide reflections are correlated only tentatively with other sections as their sanidine composition does not allow us to prove or refute correlations. Trace elements that helped correlation of these beds in Saaremaa have not been analysed in Aizpute. On the other hand, the number of beds with wide reflections at close stratigraphical levels is similar in Saaremaa and Aizpute (5 and 6, respectively). In Table 1 the supposed preliminary correlation is given with smaller font. The bed at $953.99 \mathrm{~m}$ in Aizpute, containing sanidine with a high sodium content, and the bed at $369.12 \mathrm{~m}$ in Ohesaare with high $\mathrm{Nb}$ and $\mathrm{Zr}$ (Kiipli \& Kallaste 1996) were correlated by analogy with other beds with high $\mathrm{Nb}$ and $\mathrm{Zr}$ contents and sodium-rich sanidine (beds 2, 17, 19, 20, Kiipli 1998). Direct correlation using the same criterion is not possible as no more sample material for analyses is available from these beds.

Depths of volcanic beds above $940 \mathrm{~m}$ in the Aizpute section must be considered as conventional, as drilling depth records allow different interpretations in the range $\pm 2-3 \mathrm{~m}$. Comparison with biostratigraphic analyses is possible only by using sampling markers on core boxes.

Sanidine from $370.77 \mathrm{~m}$ in Ohesaare shows a somewhat different diffractogram for bed 2 compared to the others. It has a characteristic sharp peak, but also a wide tail-like reflection. It was noticed in the process of the preparation of the sample that this thin bed consisted of two visually different parts. Therefore we suppose that the sample consists of a mixture of two successive eruptions (beds 2 and 3) and sediment thickness between these beds is reduced to zero in Ohesaare (0.5 $\mathrm{m}$ in the Viki core).

\section{CONCLUSIONS}

1. The composition of magmatic $\mathrm{K}-\mathrm{Na}$ sanidine in volcanic ash beds is a valuable tool for identification of coeval beds in sections, allowing crossing the facies boundaries. 
2. Correlations of volcanic ash beds of shallow shelf sections and the deep shelf Ohesaare section generally confirm but enable also some refinements of graptolite- and conodont-based correlations by Loydell et al. (1998).

3. Correlations based on many volcanic beds reveal sedimentological features (condensation of sedimentation, facies movements) difficult to establish by other methods.

\section{ACKNOWLEDGEMENTS}

We thank the referees D. Kaljo and S. Snäll for useful remarks which considerably improved the manuscript. Financial support for this research was provided by the Estonian Science Foundation (grant No. 4070).

\section{REFERENCES}

Aaloe, A. 1960. New research into the Silurian stratigraphy of Estonia. Eesti TA Geol. Inst. Uurimused, 5, 123-141 (in Russian).

Altaner, S. P., Hower, J., Whitney, G. \& Aronson, J. L. 1984. Model for K-bentonite formation: evidence from zoned K-bentonites in the disturbed belt, Montana. Geology, 12, 412-415.

Batchelor, R. A. \& Jeppsson, L. 1994. Late Llandovery bentonites from Gotland, Sweden, as chemostratigraphic markers. J. Geol. Soc. London, 151, 741-746.

Bergström, S. M., Huff, W. D., Kolata, D. R. \& Bauert, H. 1995. Nomenclature, stratigraphy, chemical fingerprinting, and areal distribution of some Middle Ordovician K-bentonites in Baltoscandia. $G F F, 117,1-13$.

Bergström, S. M., Huff, W. D. \& Kolata, D. R. 1998. The Lower Silurian Osmundsberg K-bentonite. Part I: stratigraphic position, distribution, and palaeogeographic significance. Geol. Mag., 135, $1-13$.

Caballero, E., Reyes, E., Delgado, A., Huertas, F. \& Linares, J. 1992. The formation of bentonite: mass balance effects. Appl. Clay Sci., 6, 265-276.

Grim, R. E. \& Güven, N. 1978. Bentonites. Geology, mineralogy, properties and uses. Developments Sedimentol., 24.

Huff, W. D., \& Kolata, D. R. 1989. Correlation of K-bentonite beds by chemical fingeprinting using multivariate statistics. In Quantitative Dynamic Stratigraphy (Cross, T. A., ed.), pp. 567-577. Prentice Hall.

Huff, W. D., Kolata, D. R., Bergström, S. M. \& Zhang, Y.-S. 1996. Large-magnitude Middle Ordovician volcanic ash falls in North America and Europe: dimensions, emplacement and post emplacement characteristics. J. Volcanol. Geothermal Res., 73, 285-301.

Jeppsson, L. \& Männik, P. 1993. High resolution correlations between Gotland and Estonia near the base of the Wenlock. Terra Nova, 5, 348-358.

Johnson, M. E., Baarli, B. G., Nestor, H., Rubel, M., \& Worsley, D. 1991. Eustatic sea level patterns from the Lower Silurian (Llandovery Series) of Southern Norway and Estonia. Geol. Soc. Amer. Bull., 103, 315-335.

Kaljo, D. 1962. On the boundary of the Llandoverian and Wenlockian in the East Baltic. Eesti TA Geol. Inst. Uurimused, 10, 97-113 (in Russian).

Kaljo, D., Kiipli, T. \& Martma, T. 1998. Correlation of carbon isotope events and environmental cyclicity in the East Baltic Silurian. In Silurian Cycles (Landing, E. \& Johnson, M. E., eds.). New York State Mus. Bull., 491, 297-312. 
Kastner, M. 1971. Authigenic feldspars in carbonate rocks. Amer. Mineral., 56, 1403-1442.

Kastner, M. \& Siever, R. 1979. Low temperature feldspars in sedimentary rocks. Amer. J. Sci., 279, 435-479.

Kiipli, E. \& Kallaste, T. 1996. Geochemical characterization of some Estonian metabentonites. Proc. Estonian Acad. Sci. Geol., 45, 68-77.

Kiipli, T. 1998. Vulkanogeensed kihid Eesti settekivimites. In 60 aastat mäeinseneride ópetamist Eestis (Reinsalu, E., ed.), pp. 9-12. Tallinna Tehnikaülikool Mäeinstituut, Tallinn.

Kiipli, T. \& Tsegelnjuk, P. D. 2001. Rare metals in volcanic ash beds in Silurian sedimentary sections of Estonia, Ukraine and Moldova - application for correlations between regions. In Rare Metals in Ukraine - View to the Future (Galetsky, L. S., ed.), pp. 59-61. Acad. Sci. Ukraine, Kiev.

Kiipli, T., Kiipli, E. \& Kallaste, T. 1997. Metabentonite composition related to sedimentary facies in the Lower Silurian of Estonia. Proc. Estonian Acad. Sci. Geol., 46, 93-104.

Kiipli, T., Männik, P., Batchelor, R. A., Kiipli, E., Kallaste, T. \& Perens, H. 2001. Correlation of Telychian (Silurian) altered volcanic ash beds in Estonia, Gotland and Norway. Norwegian J. Geol., 81, 179-193.

Loydell, D. K., Kaljo, D. \& Männik, P. 1998. Integrated biostratigraphy of the lower Silurian of the Ohesaare core, Saaremaa, Estonia. Geol. Mag., 135, 769-783.

Männik, P. \& Viira, V. 1990. Conodonts. In Field Meeting Estonia 1990. An Excursion Guidebook (Kaljo, D. \& Nestor, H., eds.), pp. 84-89. Inst. Geol. Estonian Acad. Sci., Tallinn.

Nestor, H. 1997. Silurian. In Geology and Mineral Resources of Estonia (Raukas, A. \& Teedumäe, A., eds.), pp. 89-106. Estonian Acad. Publ., Tallinn.

Nestor, V. 1994. Early Silurian chitinozoans of Estonia and North Latvia. Academia, 4, Estonian Acad. Publ., Tallinn.

Orville, P. M. 1967. Unit cell parameters of the microcline - low-albite and the sanidine high-albite solid solution series. Amer. Mineral., 52, 55-86.

Ross, C. S. \& Shannon, E. V. 1926. Minerals of bentonite and related clays and their physical properties. J. Amer. Ceramic Soc., 9, 77-96.

Spjeldnæs, N. 1959. Silurian bentonites from Gotland, Sweden. GFF, 81, 582-587.

Snäll, S. 1977. Silurian and Ordovician bentonites of Gotland (Sweden). Stockholm Contrib. Geol., 31.

Stewart, D. B. \& Wright, T. L. 1974. Al/Si order and symmetry of natural alkali feldspars, and the relationship of strained cell parameters to bulk composition. Bull. Soc. Fr. Mineral. Crystallogr., 97, 336-377.

Winchester, J. A. \& Floyd, P. A. 1977. Geochemical discrimination of different magma series and their differentiation products using immobile elements. Chem. Geol., 20, 325-343.

\title{
Eesti ja Läti madal- ja süvamere faatsieste Telychi läbilõigete korrelatsioon bentoniitide sanidiini koostise alusel
}

\author{
Tarmo Kiipli ja Toivo Kallaste
}

Röntgendifraktomeetriliselt on uuritud 12-st Adavere ja Jaani lademe läbilõikest kogutud 130 bentoniidiproovi sanidiini koostist. Selgus, et magmalises sanidiinis esineb 20-47 mol\% $\mathrm{NaAlSi}_{3} \mathrm{O}_{8}$ komponenti. Sanidiini seesugune koostis on iseloomulik paljudele vulkaanilistele kihtidele ja seda saab kasutada eri läbilõigete korreleerimisel. 


\title{
Корреляция теличских мелко- и глубоководных разрезов Эстонии и Латвии по составу санидина в бентонитах
}

\author{
Тармо Кийпли и Тойво Калласте
}

Методом рентгеновской дифракции изучено 130 проб бентонитов в целях определения в них состава санидина. Установлено, что содержание молекул натриевого полевого шпата в санидине варьирует от 20 до 47 мол\%. Каждый вулканический слой имеет свой, только ему присущий состав санидина, а поэтому может быть успешно использован для корреляции этих слоев в отдельных разрезах. 